\title{
Techno-Economic Study of PV Powered Brackish Water Reverse Osmosis Desalination Plant in the Jordan Valley
}

\author{
Ahmad Alsarayreh ${ }^{a, *}$, Mohammad Majdalawi ${ }^{b}$, Ramchandra Bhandari $^{c}$ \\ ${ }^{a}$ Independent researcher in Renewable Energy, Amman, Jordan \\ ${ }^{b}$ University of Jordan, Amman, Jordan \\ ${ }^{c}$ TH Köln - University of Applied Sciences, Cologne, Germany
}

\begin{abstract}
Jordan is one of the ten most water scarce countries in the world. In 2014, the share of water per capita per year in Jordan is 120 Cubic Meters $\left(\mathrm{m}^{3}\right)$. The water deficit is estimated to be 160 Million Cubic Meter (MCM) in 2015. This deficit is projected to grow up to $490 \mathrm{MCM}$ by 2025 . This study discusses the possibility of using solar energy for brackish water desalination in Jordan Valley (JV) to reduce the pressure on the fresh water and the conventional energy consumption associated with the desalination process, as well as, to reduce Greenhouse Gases (GHG) emissions associated with the consumption of energy produced from fossil fuels. Photovoltaic (PV) powered brackish water reverse osmosis desalination technology (RO) has been investigated in this study. The PV system has designed using PVSOL software. The economic feasibility study of use PV system has been done using Average Incremental Cost of Water (AICOW), Internal Rate of Return (IRR) and Net Present Value (NPV) in several scenarios. The results of the analysis showed that using PV systems for brackish water desalination for a small size single plant at current electricity tariff is not economically feasible for the farmers. But it is feasible for a larger size plant for ten farms or more, or with financial support from the government. The feasibility results showed that using PV systems for brackish water desalination for the government side are economically feasible even for a small size plant.
\end{abstract}

Keywords: Desalination, Brackishwater, Solar Energy, Photovoltaic.

\section{Introduction}

Jordan is one of the ten most water scarce countries in the world; it is rated as the third country at extreme risk in the water security risk index and map as shown in Figure 1.This index has been developed by Maplecroft, the global risk analysis firm. The water scarce countries are the countries with less than 1,000 $\mathrm{m}^{3}$ per capita per year $[1]$.

In Jordan, the water demand highly exceeds the supply; where in 2015 the estimated water deficit in Jordan was 160 Million Cubic Meter (MCM), which is projected to grow up to 490 MCM by 2025 [3]. About $64 \%$ of water consumption in Jordan is consumed by the agriculture sector in Jordan Valley (JV) and highlands.

\footnotetext{
${ }^{*}$ Corresponding author.

E-mail: Ahmadsarayrah@Ymail.com

(C) 2017 International Association for Sharing Knowledge and Sustainability

DOI: 10.5383 /ijtee.14.01.010
}

\begin{abstract}
The previously mentioned facts clearly show that there is an immediate need to develop and find new optional water resources in Jordan. Desalination of brackish water is considered one of the important optional sources for agriculture sector in the JV to meet the rapid growing of water demand. About 80 MCM of brackish water with average salinity 3000 Part Per Million (ppm) can be used in the JV as indicated in some studies [4].To adapt desalination technologywe must evaluate this option in integrated manner take in the consideration all the challenges mainly the energy side; where water and energy are inseparably linked and energy is required for water desalination, the energy cost in desalination plants comprises up to $50 \%$ of the total cost of the produced water [5].
\end{abstract}

Since Jordan depends totally on imported crude oil and some petroleum products to meet domestic energy demand, a clear strategy of how to manage the trade-offs between water and energy in sustainable way is needed. Nevertheless, Jordan lies in the - global sunbelt area which has abundant supplies of solar energy, with relatively high average daily solar radiation of 5.5 
$\mathrm{kWh} / \mathrm{m}^{2}$ day, and the annual sunshine duration is around 2,900 hours [6]. These conditions can be considered sufficient to provide enough energy for water desalination and to lead to significant reduction in the total cost of desalination and seems to be more feasible to use a renewable energy for that.

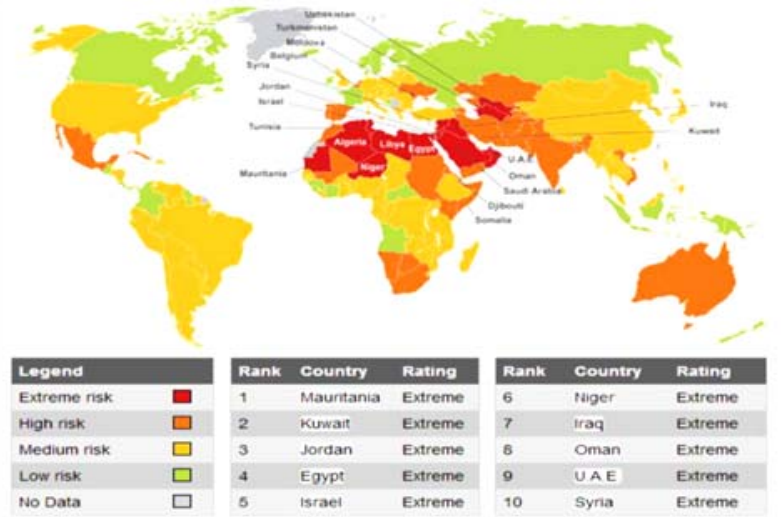

Fig. 1: Water security Index [2]

\section{Previous studies}

Very limited research have been done in using renewable energy for brackish and sea water desalination in Jordan. A study has been done to evaluate various desalination technologies for brackish water in Jordan which are RO, Electro-Dialysis (ED), Vapor Compression (VC), Multi-Stage Flash Distillation (MSF), and Multiple Effect Distillation (MED). The study was based on multi-criteria analysis included technical, economic, and environmental aspects. The relative global weights for five desalination technology were outlined in the study. The analysis revealed that $\mathrm{RO}$ system is the most favorable option under the investigated criteria [7].

A technical feasibility study to investigate the potential of using stand-alone PV systems for small scale desalination plants for brackish water in the JV has been carried out and it has showed that the costs for $1 \mathrm{~m}^{3}$ of water about 2.43 Euro by using PV system compared to 4.80 EUR by using a diesel generator [8].Another study investigated the potential of wind energy for water desalination in Jordan. The study identified the potential hotspotsareas for wind-powered desalination plants; these areas include Hofa, Kamsha, Aqaba, Tafila, Al-Reesheh and Al-Harir. The potential water production respectively was $1,690 \mathrm{~m}^{3} /$ day, $1,744 \mathrm{~m}^{3} /$ day, $1,635 \mathrm{~m}^{3} /$ day, $2,660 \mathrm{~m}^{3} /$ day, $1,537 \mathrm{~m}^{3} /$ day, and $3,074 \mathrm{~m}^{3} /$ day [6].

For seawater desalination a study has been done to create a generalized method to determine the engineering feasibility of community scale, photovoltaic powered seawater and brackish water RO systems. The analysis showed that the feasibility is a function of location due to variation in solar resource, water type, system demand and local governmental policies. For Aqaba city the cost of water from solar driven RO compared to diesel driven RO respectively is $4.43 \mathrm{EUR} / \mathrm{m}^{3}, 4.42 \mathrm{EUR} / \mathrm{m}^{3}$ [9].

For using renewable energy for brackish in Jordan's neighbor countries an optimization study was carried in Egypt to design the efficient economic renewable energy system that drive a small scale BWRO desalination unit for a hotel located in Hurghada, Egypt by using HOMER software. Four renewable energy systems were investigated in the study which are: PV- wind hybrid system, stand-alone wind system, stand-alone PV systemand PV-wind-fuel cell hybrid system. The study shows that the PV-wind hybrid system is the lowest net present cost, minimum cost of energy and able to drive the RO unit approximately all the day [10].

A technical economic feasibility study in Iraq (East of Jordan), to assess the economic and technical performance of a mediumcapacity RO desalination plant $\left(2,000 \mathrm{~m}^{3} /\right.$ day $)$, that proposed to be installed in Umm Qasr city south of Basra, has been done and showed that the total water production cost is $0.79 \mathrm{EUR} / \mathrm{m}^{3}$. This is a reasonable cost considering the size of the plant, the remoteness, and the unavailability of fresh water in this region. The quality of the produced water $(279 \mathrm{ppm})$ is excellent and well within the World Health Organization (WHO) requirement [11].

\section{SYSTEM DESIGN}

In order to investigate the feasibility of PV powered BWRO plant in the JV; a proposed plant in the South Shouneh area for a banana farm with similar to real cases conditions was analyzed in this study, the proposed plant size is $24 \mathrm{~m}^{3} / \mathrm{hr}$ as common size in the market. Figure 2 depictsa schematic diagram of the proposed system; this diagram illustrates the main parts that make up the system, water quantity and quality. From the illustration sketch the system consists of: PV system, treatment Plant, Pumps (submersible pump, rejected brine pump, RO plant pump, irrigation pump), water well, and brackish water and fresh water pools.

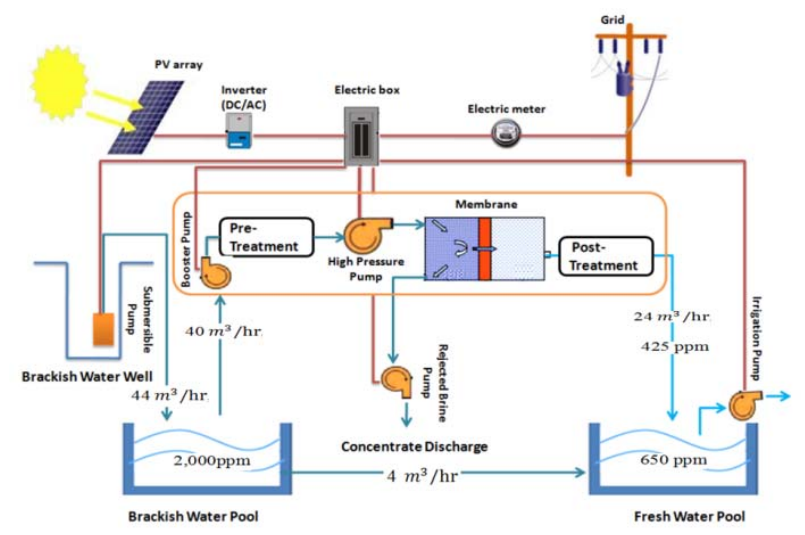

Fig.2: The proposed system schematic diagram

The proposed treatment plant is developed and manufactured by the New World Water Technology (NWWTECH), one of the leader Jordanian companies in gathering and manufacturing the RO units. The plant consists of three main steps which are; pretreatment, RO, and post treatment. Figure 3 illustrates the main components of the treatment plants.

\subsection{Sand filter:}

A pre-treatment component is used to remove suspended or dissolved particles with a size about 20 - 50 micron from water in order to protect the membrane surface and to minimize the fouling problem.

\subsection{Cartridge filter:}

After the sand filter the water also re-filtrated by cartridge filter to remove the small particles that have a size about 5 micron. 


\subsection{High pressure pump:}

After the water has passed the cartridge filters, the high-pressure pump pressurizes the pretreated brackish water to the operation pressure which is about 20 bar for the proposed plant.

\subsection{RO membrane elements:}

In the membrane elements the main step is the RO desalination process where the water flows across the membrane, leaving the salts to retain by the reverse osmosis process. The proposed plant use 24 spiral wound elements with diameter 8 inch and 40 inch length.

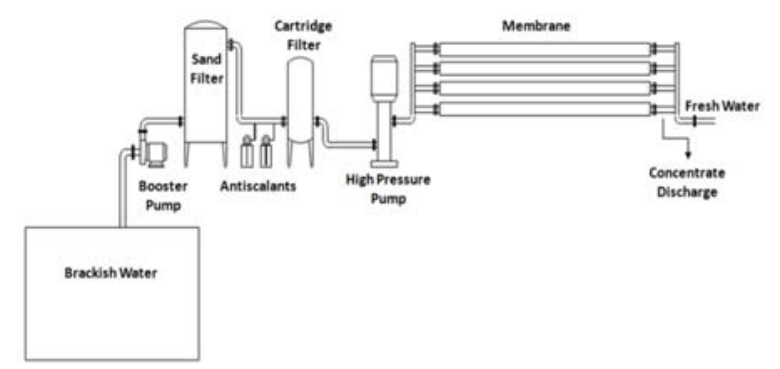

Fig.3: Schematic diagram of the treatment plant

\section{Water and energy demand analysis}

The water demand analysis is an important step to determine the system operation hours in different year periods and the total energy consumption for the PV system sizing. The water demand calculations were done based on the actual water demand for banana in the South Shouneh. Table 1 shows the water supply schedule for banana in South of JV area per dunum ( 1 dunum equal to $1000 \mathrm{~m}^{2}$ ). Figures 4 and 5 show the profile of annual estimated water and energy demands, the water and energy demands calculations were done based on the actual water demand for banana in the South Shouneh and the RO plants and pumps power rate.

Table 1: Water supply schedule for agricultural Units in South Area [12]

\begin{tabular}{|l|c|}
\hline Date & $\begin{array}{c}\text { Daily Supplied } \\
\left(\mathrm{m}^{3} / \text { Dunum }\right)\end{array}$ \\
\hline 1-30 April & 4.4 \\
\hline 1 May - 15 June & 6.6 \\
\hline 16 June - 15 September & 8.8 \\
\hline $\begin{array}{l}\text { 16 September - 31 } \\
\text { October }\end{array}$ & 6.6 \\
\hline 1 November - 31 March & 3.3 \\
\hline
\end{tabular}

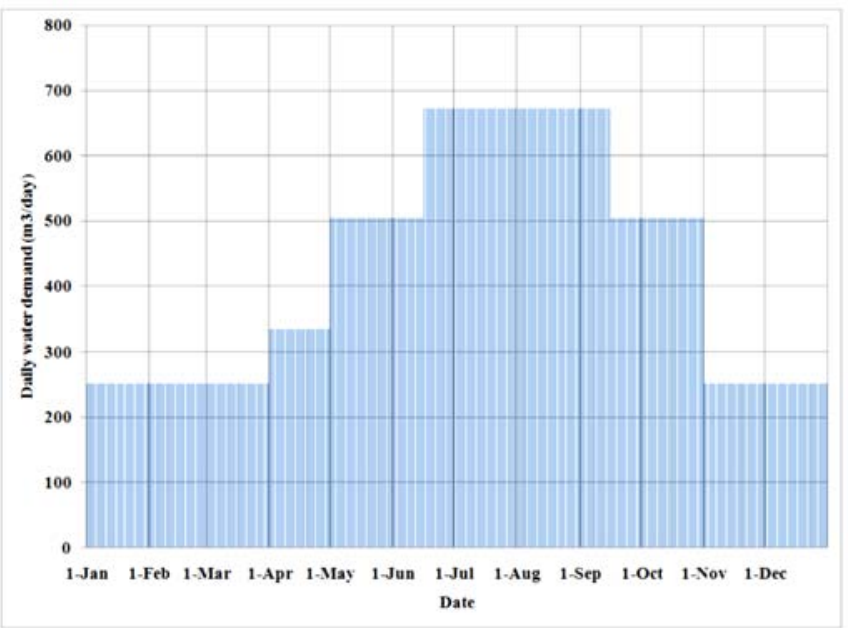

Fig.4: Estimated water demand versus time

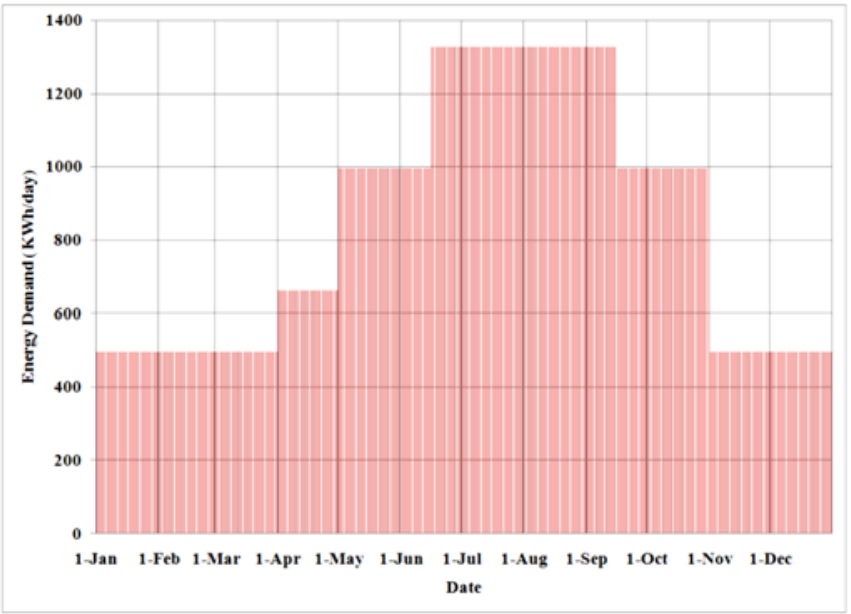

Fig. 5: Estimated energy demand versus time

\section{PV system sizing}

The PV system was designed for on grid net metering connection, and based on the regulatory directives that have been issued by the Jordanian Electricity Regulatory Commission (ERC) pursuant to article (10/B) of the renewable energy and energy efficiency law No.(13), for the year 2012; for the small scale projects less than $5 \mathrm{MW}$ the maximum installed renewable energy system capacity shall not exceed $1 \%$ of the maximum electrical load.

In this study Trina TSM-PC14A 300 solar panels (Si polycrystalline) with rated power $300 \mathrm{~W}$, manufactured by Trina Solar as one of the world's leading PV companies were selected. The study assumed these panels orientation to the south with $0^{\circ}$ azimuth angle and $29^{\circ}$ Inclination angle. The selected proposed inverter is TRIO-27,6-TL-OUTD which manufactured by Power-One. The system sizing was simulated by $\mathrm{PV} * \mathrm{SOL}$ premium 7.0 software which is a dynamic simulation software for photovoltaic planning, design and optimization of gridconnected and on-grid photovoltaic systems. This software is produced by Valentin Software, a specialized company in the dynamic simulation, design, yield calculation and financial prognosis of photovoltaic, solar thermal and heat pump systems software. The software takes into consideration the local 
climatic conditions, and the actual variable system efficiencies and expected losses.

The simulation results show that the treatment plant and the irrigation pump need for 576 panels type Trina TSM-PC14A 300 , these panels distributed for 6 strings connected in parallel, each string connected with one TRIO-27,6-TL-OUTD inverter. This system can produce $172.8 \mathrm{kWp}$, and $312.714 \mathrm{kWh}$ of electricity annually which will cover all the energy demand for the proposed desalination system, the sizing factor is $100 \%$. Figure 6 shows the monthly system energy balance. Because of the water demand profile the energy consumption in the summer season exceeds the produced energy from the PV system, while in the winter season the produced energy from PV system exceeds the energy demand, therefore the farmer can get benefit and feeds electricity into the grid during the winter season as shown in Figure 6.

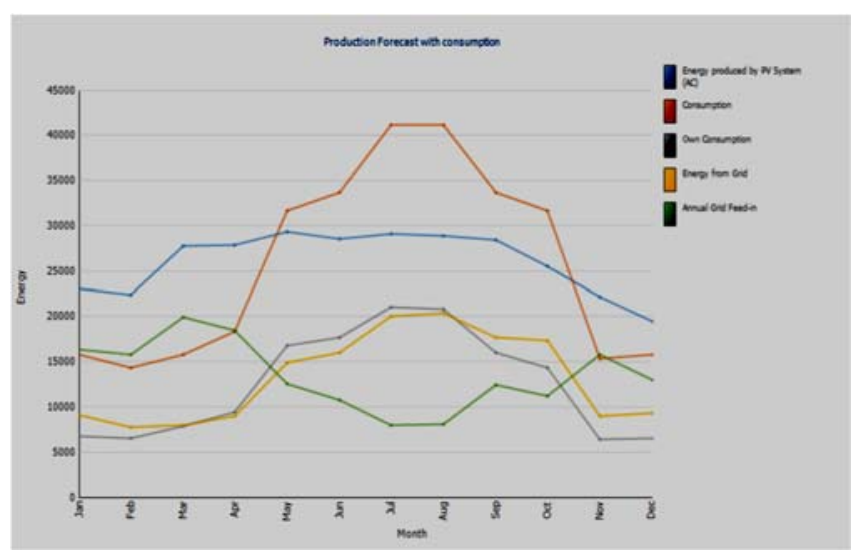

Fig. 6: Monthly system energy balance (in KWh)

\section{Financial feasibility analysis results}

In this study, Average Incremental Cost of Water (AICOW), Internal Rate of Return (IRR), and Net Present Value (NPV) methods were used as economic indicators to investigate of using PV system for BWRO desalination in the JV. The AICOW and IRR for the farmer were calculated within three scenarios: A. Based on the current electricity tariff for the agriculture sector which is $6.30 \mathrm{EUR} / \mathrm{kWh}$, considering different level of cost reduction of the PV system.

B. Based on the electricity tariff for the agriculture sector increased by $50 \%$ to reach $9.45 \mathrm{EUR} / \mathrm{kWh}$, with several assumptions if the Cost Reduction (CC) of the PV system decreased.

C. For a central BWRO plant for ten farms at current electricity tariff for the agriculture sector.

The results for scenario A as shown in table 2 show that there is no huge reduction on AICOW with using PV system without CC reduction. The IRR is also low; it is $9.2 \%$ which makes the project is economically unfeasible for the farmers.

The results show that if the CC of the PV system reduced to $20 \%$ there will be somehow considerable reduction on the AICOW but still low, the estimated IRR is $12.7 \%$ which means that the use of PV system is economically feasible for the Farmers.
The results for scenario $\mathrm{B}$ show that there is a considerable reduction on AICOW with using PV system even without reduction of PV system CC. The IRR result also shows that using PV system is economically feasible even without any reduction on the PV system cost.

The study investigated the economic feasibility for a central Brackish Water Reverse Osmosis (BWRO) plant for ten farms (scenario $\mathrm{C}$ ), the result as presentedin table 3 shows that the IRR for central plant is $11.9 \%$ which means that the central plant for ten farms or more is economically feasible for the Farmers even without any reduction in the PV system cost. This could be done by internal agreement between the farmers to share the plant cost, or to build a large plant by one farmer or investor and he will sell the fresh water for otherfarmers. In this case,the ministries of water and energy should adapt new strategies and regulations on selling brackish water for solar desalination purposes.

Table 2: AICOW Vs. electricity tariff and PV system CC reduction

\begin{tabular}{|c|c|c|c|c|c|c|}
\hline Scenario & AICOW (EUR cent $/ \mathrm{m}^{3}$ ) & \multicolumn{5}{|c|}{ AICOW (EUR cent $/ \mathrm{m}^{3}$ ) - RO+PV } \\
\cline { 3 - 7 } & \multirow{2}{*}{-RO } & & \multicolumn{5}{|c|}{ PV system cost reduction } \\
\cline { 3 - 7 } & & $0 \%$ & $5 \%$ & $10 \%$ & $15 \%$ & $20 \%$ \\
\hline A & 24.4 & 23.1 & 22.3 & 21.6 & 20.9 & 20.2 \\
\hline B & 30.6 & &
\end{tabular}

Table 3: IRR Vs. electricity tariff and CC reduction

\begin{tabular}{|c|c|c|c|c|c|}
\hline \multirow{2}{*}{ Scenario } & \multicolumn{5}{|c|}{ PV system cost red uction } \\
\cline { 2 - 6 } & $0 \%$ & $5 \%$ & $10 \%$ & $15 \%$ & $20 \%$ \\
\hline A & $9.2 \%$ & $10.0 \%$ & $10.8 \%$ & $11.7 \%$ & $12.7 \%$ \\
\hline B & $16.6 \%$ & $17.8 \%$ & $19.0 \%$ & $20.5 \%$ & $22.1 \%$ \\
\hline C & 11.996 & $12.8 \%$ & 13.796 & $14.8 \%$ & 16.096 \\
\hline
\end{tabular}

Where Jordan's Government supports the electricity and there is a benefit for the government from using the PV systems, so the NPV was investigated for the farmers and the government in a new scenario (Scenario D).Four cases were investigated in this scenario D, the first with current electricity cost, and the other three scenarios with electricity cost reduction by $10 \%, 20 \%$, and $30 \%$.The analysis results show that the NPV is positive for the government if it contributes to the PV system investment by up to $100 \%$ even if the electricity price reduced by $30 \%$. The analysis shows that the NPV for the Government higher than the NPV for the Farmer even if it covers all the PV system investment cost, and the IRR for the government in this case is $26 \%$. But if the electricity cost reduced by $10 \%, 20 \%$ and $30 \%$ the optimum governmental share is $92 \%, 76 \%$, and $60 \%$ where the NPV for the government equal the NPV for the farmer while the IRR is $24 \%$ for the three cases. Figures 7 to 10 show the NPV calculation results. 


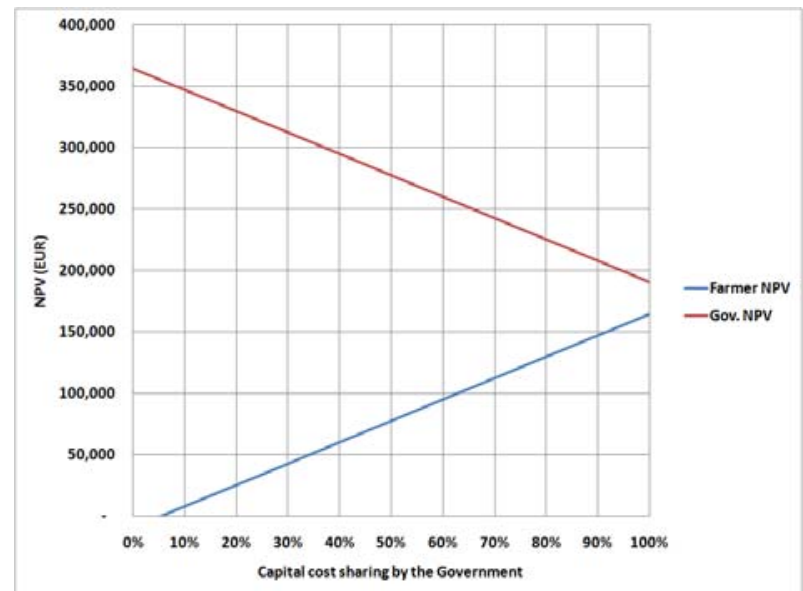

Fig. 7: NPV for the farmer and government at current electricity cost

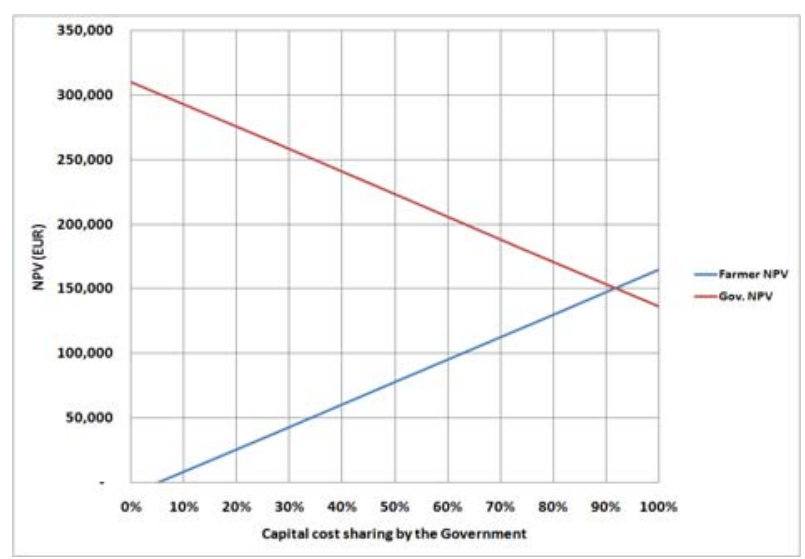

Fig. 8:NPV for the farmer and government at $10 \%$ reduction on electricity cost

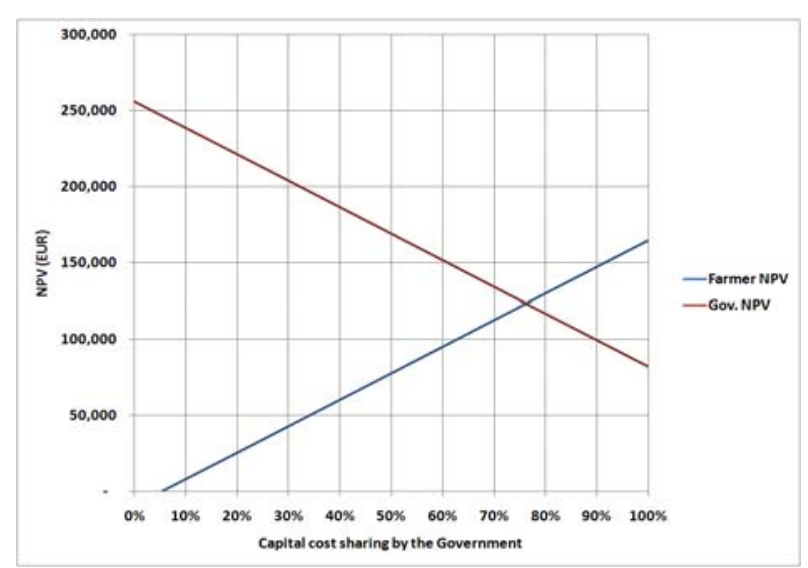

Fig. 9: NPV for the farmer and government at $20 \%$ reduction on electricity cost

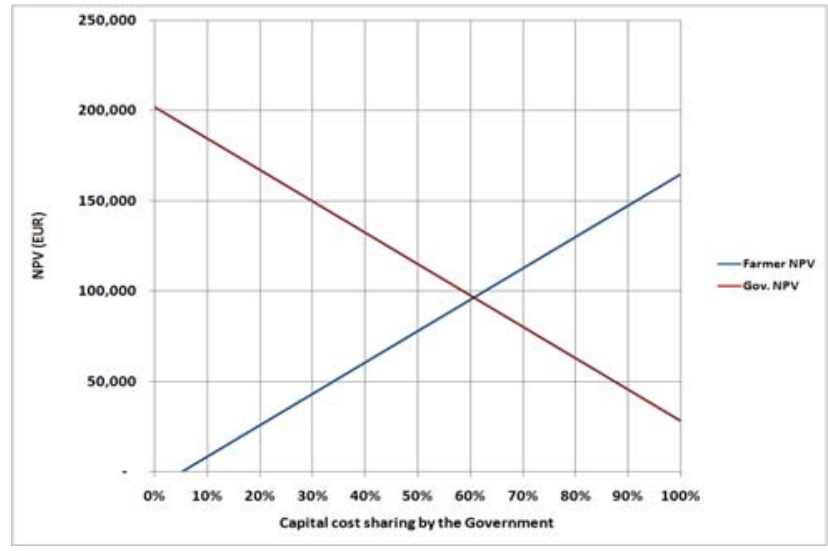

Fig. 10: NPV for the farmer and government at $30 \%$ reduction on electricity cost

\section{Environmental analysis}

One of the main reasons for using solar energy is to reduce the global warming resulting from the Green House Gases (GHG) associated with conventional system operating and its effect on water shortage in the world and Jordan as well the GlobalWarming Potential (GWP) is a relative measure of how much heat a greenhouse gas traps in the atmosphere to the amount of heat trapped by a similar mass of carbon dioxide $\left(\mathrm{CO}_{2}\right)$. The $\mathrm{CO}_{2}$ saving in the proposed system calculated from the $\mathrm{CO}_{2}$ emissions factor per $\mathrm{kWh}$ generated (C), take in the account the transmission and distribution losses (T\&D). The saving can be calculated as below equation:

$\mathrm{CO}_{2}$ saving $=$ Annual energy saving $\times(1+\mathrm{T} \& \mathrm{D}) \times \mathrm{C}$

(Eq.1)

Based on $\mathrm{C}$ for Jordan $=0.644 \mathrm{KgCO}_{2} / \mathrm{KWh}^{2}$ [13]. And the $\mathrm{T} \&$ $\mathrm{D}$ losses in Jordan are 15\% [14]; the estimated annual $\mathrm{CO}_{2}$ saving in:

$229,103 \mathrm{KgCO}_{2}$

\section{Conclusions \& Recommendations}

The main findings of this work are as follow:

- The investigated proposed plant in this study shows that using PV systems for brackish water desalination at current electricity tariff is not economically feasible for the farmers.

- The investigated proposed plant in this study shows that using PV systems for brackish water desalination is economically feasible for the farmers if:

- $\quad$ The electricity tariff increased $50 \%$.

- $\quad$ Reduction in the initial cost by more than $20 \%$.

- Financial support from the government.

- The investigated proposed plant in this study shows that using PV systems for brackish water desalination is economically feasible for the government even if the electricity tariff increased by $50 \%$ or the electricity cost decreased by $30 \%$.

- There are environmental benefits for the proposed system, as GHG reduction. 


\section{References}

[1] FAO Food and Agriculture Organization, Review of World Water Resources by Country 2003, Rome, Italy.

[2] Maplecroft, Water Security Index, Retrieved December, 21, 2013, from http://maplecroft.com/about/news/water_security.htm $1,2011$.

[3] Ministry of Water and Irrigation (MWI) Water Budget 2009/2010 cited in USAID, Review of Water Policies in Jordan and Recommendations for Strategic Priorities, Final Report, April 2012, p.x.

[4] Mohsen, M. \&Gammoh, S., Performance Evaluation of Reverse Osmosis Desalination Plant: A Case Study of WadiMa in, Zara and Mujib Plant. Desalination and Water Treatment 2010, 14, pp.265-272.Doi: $10.5004 /$ dwt.2010.1873

[5] Ghali K., Ghaddar, N. \&Alsaidi A. optimized operation of an integrated solar desalination and airconditioning system: theoretical study, European Association for the Development of Renewable Energies 2010

[6] Mohsen, M. Potential for Wind-Powered Desalination Systems in Jordan.International Journal of Thermal and Environmental Engineering 2010, 1(2), pp.109123. DOI: 10.5383 ijtee.01.02.007

[7] Mohsen, M.S. \& Al-Jayyousi, O.R. Brackish Water Desalination: an Alternative for Water Supply Enhancement in Jordan. Desalination 1999, 124(1-3), pp.163-174. DOI: 10.1016/S0011-9164(99)00101-0

[8] Muhaidat, A. Al-addous, M. Alawneh, F. \& Class, C. B. A Photovoltaic System for Small Scale Brackish
Water Desalination in Remote Areas.Proceedings at the International Conference on Solar energy for MENA region (INCOSOL),2012, pp.22-23.

[9] Bilton, A.M. Wiesman, R. Arif, A. F. M. Zubair, S. M. \&Dubowsky, S. On the feasibility of community-scale photovoltaic-powered reverse osmosis desalination systems for remote locations. Renewable Energy 2011, 36, pp.3246-3256

[10] Fahmy, F.H., Ahmed, N.M. \&Farghally, H.M. Optimization of Renewable Energy Power System for Small Scale Brackish Reverse Osmosis Desalination Unit and a Tourism Motel in Egypt, 2012February, pp.43-50. DOI: 10.4236/sgre.2012.31006

[11] Al-karaghouli, A. \&Kazmerski, L. Economic and Technical Analysis of a Reverse-Osmosis Water Desalination Plant using DEEP-3 .2 Software.Proceedingsat the World Renewable Energy Congress XI, September 2010, Abu Dhabi, United Arab Emirates,pp. 1-5

[12] Edgar, A. N. Crop Water Use Efficiency by Type of Crop and Farming System in the Jordan Valley. KAFA'A Knowledge and Action, 2014. Fostering Advances in Agriculture. Development Alternatives, Inc.

[13] Brander, M. Sood, A. Wylie, C. Haughton, A. \& Lovell, J. Technical Paper, Electricity-specific emission factors for grid electricityAugust2011, pp.122 .

[14] The World Bank, Electric power transmission and distribution losses (\% of output), Retrieved, November, $\quad 10, \quad 2014, \quad$ from http://data.worldbank.org/indicator/EG.ELC.LOSS.Z 